\title{
TERMINOLOGICAL PATTERNS AND THE DIVINE EPITHET SHADDAI
}

\author{
W. Warning
}

\begin{abstract}
Summary
By juxtaposing the first seven occurrences of the divine epithet Shaddai in Genesis and Exodus it becomes evident that they are both terminologically and thematically interrelated and culminate in Exodus 6:3.

Concordances, and even more so today Bible computer programmes, are a means of gaining insight into the 'workshop' of the author of the Endgestalt, or final shape, of a given biblical text, because by making use of the computer the distribution of a given word can easily be traced. In some recent studies the vocabulary of certain passages of the Pentateuch has been scrutinised by tabulating all the words used in a given self-contained literary unit, an entity which may consist of a brief passage, a chapter or even a biblical book, thus bringing to light the distinct distribution, the relative frequency and the structural positioning of significant terms and/or phrases. ${ }^{1}$ By carefully tabulating their respective positions and counting the frequencies of the words used, several terms turn out to be significant as far as structural outlines are concerned, and it is these structures based on counting a given sentential entity, word or term, which have been called 'terminological patterns'. In each of these studies it has been shown that the extant text has been carefully composed by its ancient author, the term 'author' being understood and used as referring to the person(s) responsible for the text before us, the person(s) who
\end{abstract}

1 W. Warning, Literary Artistry in Leviticus (BInS 35; Leiden: E.J. Brill, 1999) presents terminological patterns based on the number seven $(66-82 ; 133-36)$, chiastic structures $(82-101 ; 136-42)$, numerological structures $(101-115 ; 142-56)$, open-envelope structures $(115-20 ; 156-59)$, and envelope structures $(120-24 ; 159$ 60). Preliminary research has brought to light the same type of terminological patterns in the books of Esther, Isaiah, Amos and Micah.

2 Warning, Artistry, 25. 
composed the literary unit we call, for instance, 'Genesis 17', 'the Joseph Story' or 'Genesis', literary entities which did not exist prior to their composition, whatever the prehistory of their individual parts may have been.

Close reading of different biblical texts has provided another insight: Because of the symbolic significance ascribed by the ancients to the number seven (representing completion and completeness) in a variable-length list the seventh and, in case of a longer list, at times the twelfth position tend to be emphasised by means of some special term or phrase. ${ }^{3}$ It is my contention that the author of the extant text has employed this structural device in using the divine epithet Shaddai. Since this study is solely concerned with the final text, any discussion of sources and actual or alleged literary layers has deliberately been omitted.

In the Pentateuch the epithet Shaddai is used first in Genesis 17:1 and furthermore in Genesis $28: 3 ; 35: 11 ; 43: 14 ; 48: 3$; 49:25; Exodus $6: 3$ and Numbers $24: 4,16$. The present study focuses on its distribution in the extant text of the Pentateuch, but it is only the first seven of the nine occurrences which will be scrutinised. ${ }^{4}$ In further narrowing down the scope of this study it should be explicitly stated that it is solely the structural aspects of the distribution of the epithet Shaddai which will be investigated, and hence any discussion of its meaning and its etymology is consciously disregarded.

In the book of Exodus the epithet appears only once, namely in 6:3: 'I appeared to Abraham, to Isaac and to Jacob as El Shaddai, but by

3 E.g. M. Paran, Forms of the Priestly Style in the Pentateuch: Patterns Linguistic Usages, Syntactic Structures (Jerusalem: Magnes, 1989 [Hebrew]), 155, 198, 204205. In the creation-story, W. Warning, 'Terminologische Verknüpfungen in der Urgeschichte', $Z A W$ (forthcoming), brings to light two structures based on the terms 'good' and 'make'. Because the two terminological patterns overlap both in the seventh (Gn. 1:31) and the twelfth ( Gn. 2:18) positions he maintains that the so-called ' $\mathrm{P}$ ' and ' $\mathrm{J}$ ' creation stories should be read as a homogeneous whole. $\mathrm{Cf}$. Warning, Artistry, 27-29, 52-54, 105-107, 110-15, 149-59; Warning, 'Terminological Patterns and the Verb מול "Circumcise" in the Pentateuch', $B N$ (forthcoming); Warning, 'Terminological Patterns and the Term עצום "Strong, Powerful" in the Pentateuch', AUSS (forthcoming).

4 The fact that in this study only the first seven occurrences of the divine epithet are being examined might arouse the reproach of arbitrariness. At this point we must not forget, however, that in numerological structures consisting of more than seven but less than twelve members it is the seventh position which is emphasised: cf. Warning, Artistry, 53-54; 105-107; 109-115; 144-46; 150-51; Warning, 'Terminologische Verknüpfungen und Genesis 12,1-3', Bib 81 (2000), 386-90; Warning, 'Terminological Patterns and Genesis 38', AUSS 38 (2000), 293-305; Warning, 'Terminological Patterns and Genesis 17', HUCA (forthcoming); Warning, 'Terminologische Verknüpfungen und Leviticus 11', $B Z$ (forthcoming). 
my name YHWH I did not make myself known to them.' In order to apprehend the structuring function of Shaddai in Genesis and Exodus and hence to appreciate its inherent theological message, it seems worthwhile to tabulate the seven texts. It is my contention that if the extant Endgestalt is taken at face value, the terminological and thematic interrelatedness of the seven texts comes clearly to light. Whereas Genesis 17:1 and 35:(9)11 constitute part of a 'divine appearance', i.e. it is explicitly stated that 'YHWH / Elohim appeared to...', in Genesis 43:3 Jacob makes reference to a divine appearance he had received years before at Luz. Finally, in Exodus 6:3 reference is made to YHWH having appeared to Abraham, Isaac and Jacob as $E l$ Shaddai. In Genesis 28:3 and 49:25 a father (Isaac and Jacob respectively) calls upon one of his sons (Jacob / Joseph) the blessing of Shaddai, and in the central text Jacob expresses his anticipation 'May El Shaddai grant you [my sons] mercy before the man' (43:14). Therefore, if we tabulate the Shaddai texts the following terminological pattern comes to light, an outline based on both terminological and thematic considerations:

\begin{tabular}{|l|l|l|l|}
\hline Gn. 17:1 & $\begin{array}{l}\text { YHWH appeared to Abram and } \\
\text { said to him: I am }\end{array}$ & El Shaddai. & \\
\hline Gn. 28:3 & May & El Shaddai & bless you. \\
\hline Gn. 35:11 & Elohim appeared to Jacob...I am & El Shaddai. & $\begin{array}{l}\text { Be fruitful and } \\
\text { multiply }\end{array}$ \\
\hline Gn. 43:14 & May & El Shaddai & $\begin{array}{l}\text { grant you mercy } \\
\text { before the man. }\end{array}$ \\
\hline Gn. 48:3 & & El Shaddai & $\begin{array}{l}\text { appeared to me at } \\
\text { Luz. }\end{array}$ \\
\hline Gn. 49:25 & $\ldots$ & Shaddai, & may he bless you \\
\hline Ex. 6:3 & $\begin{array}{l}\text { I appeared to Abraham, Isaac } \\
\text { and Jacob by my name }\end{array}$ & El Shaddai. & \\
\hline Nu. 24:4 & who sees a vision of & Shaddai & \\
\hline Nu. 24:16 & [who] sees a vision of & Shaddai & \\
\hline
\end{tabular}

Although quite distinct passages from Genesis and Exodus have been juxtaposed in the preceding table, texts which according to many a scholar originated in different eras and areas, the terminological links between the first seven texts become even clearer if we convert the terminological outline into a thematic one, an outline that somewhat resembles a chiastic structure: A (divine appearance), B (father calling blessing of Shaddai on one of his sons), C (father hopes Shaddai will 
grant safe return to his sons) and $\mathrm{AD}$ (summary reference to prior divine appearances in the seventh position):

$\begin{array}{ll}\text { A } & \text { Gn. 17:1 } \\ \text { B } & \text { Gn. 28:3 } \\ \text { A } & \text { Gn. 35:11 } \\ \text { C } & \text { Gn. 43:14 } \\ \text { A } & \text { Gn. 48:3 } \\ \text { B } & \text { Gn. 49:25 } \\ \text { AD } & \text { Ex. 6:3 }\end{array}$

divine appearance

father calls blessing of El Shaddai upon one of his sons divine appearance

father hopes El Shaddai will grant safe return to his sons reference to prior divine appearance at Luz father calls blessing of Shaddai upon one of his sons reference to prior divine appearances of El Shaddai to Abraham, Isaac and Jacob

In my view the distribution of the divine epithet is due to somebody's deliberate artistic design rather than to random order. Close reading of the patriarchal narratives seems to corroborate this hypothesis, because in Genesis many more divine 'appearances' to the patriarchs have been recorded. Whereas the above tables do not expressly mention Isaac as recipient of any appearance of Shaddai, it is mentioned twice that the LORD appeared (niphal of ראה 'see') to him, namely in Genesis 26:2, 'and YHWH appeared to him', and 26:24, 'and YHWH appeared to him that night'. Moreover, several times reference is made to YHWH / El / Elohim appearing (niphal of הNר) to Abraham and Jacob respectively: Genesis 12:7: 'and YHWH appeared to Abram / '...YHWH who had appeared to him'; 18:1: 'and YHWH appeared to him'; 35:1: '...to $E l$ who appeared to you'; 35:9: 'and Elohim appeared to Jacob'. In view of these divine appearances mentioned in the extant text, the structural significance of the distinct distribution of Shaddai probably gains support. The seven-part outline with its significant seventh position seems to be based both on terminological and thematic considerations.

In the above table it is in the seventh position that retrospectively, as it were, reference is made to YHWH's appearing to Abraham, Isaac and Jacob. By means of the terminological and thematic outline different pericopes of the patriarchal narratives have been correlated and closely connected with Exodus 6:3. In view of the fact that this structure comes to light only after having made the final text, the only fact available to us, 5 our point of departure, this heretofore unknown linguistic link probably deserves the readers' attention. The profusion of the divine appearances and the bounteous blessings given by the Lord to the patriarchs are obviously enhanced by placing the 'summary statement' in the significant seventh slot.If it is true to fact

5 Cf. R.N. Whybray, Introduction to the Pentateuch (Grand Rapids: Eerdmans, 1995), 27; R. Rendtorff, Leviticus (BKAT 3,1; Neukirchen-Vluyn: Neukirchener Verlag, 1985), 4 . 
that in 'literature the form is meaningful...In literature the form creates meaning...In literature the meaning exists in and through form', ${ }^{6}$ this terminological pattern should be evaluated as an appropriate example, since it is in the seventh position that the different appearances of Shaddai are being wrapped up. The remarks made by C. Houtman on how best to interpret Exodus 6:3, aptly summarise the aim and purpose of this study:

Of particular importance for the interpretation of $6: 3$ is answering the question as what notions the author of Exodus associated with the name Shaddai... Whatever the case may be, it is unlikely that in $6: 3$ the author/editor of Exodus aimed to notify readers concerning how the name YHWH became known. The conception rooted in the pre-critical phase of biblical exegesis, which holds that God did not make his name known to Moses, but told him instead that from now on He would manifest himself with other qualities than was during the period of the patriarchs, does the most justice to the text of Exodus in its present form. God manifested himself to the fathers as El Shaddai, as the one who made promises...As YHWH, He acts to accomplish those promises. ${ }^{7}$

In view of the fact that in analysing the structure of a given biblical text 'our option consists of the alternative between more or less substantiated hypotheses, not between a hypothesis and no hypothesis',${ }^{8}$ we ought to be mindful that the reliability of any theory is always conditioned by its degree of explanatory power. Since it is true that in matters like these all we can aspire to is to elevate a possibility into a serious probability, the reader is called upon to weigh the evidence personally and to decide whether the approach presented here should be seriously taken into consideration.

6 L. Alonso-Schökel, 'Hermeneutical Problems of Literary Study of the Bible', SVT Congress Volume 28: Edinburgh 1974 (Leiden: E.J. Brill, 1975), 7.

7 C. Houtman, Exodus, Vol. 1 (Historical Commentary on the Old Testament; Kampen: Kok Publishing House, 1993), 101-102.

8 R. Knierim, Text and Concept in Leviticus 1:1-9: A Case in Exegetical Method (Forschungen zum Alten Testament 2; Tübingen: J.C.B. Mohr, 1992), 2. 